Images in...

\title{
Misplaced central venous catheter?
}

\author{
Melissa Hempling, Andre Koletzko, Thiagarajan Jaiganesh
}

Emergency Department, St George's Hospital, London, UK

Correspondence to Thiagarajan Jaiganesh, jaiganesh@doctors.org.uk

\section{DESCRIPTION}

We report a very unusual chest x-ray finding in a 23-yearold woman who attended our Emergency Department (ED) after sustaining a respiratory arrest following a seizure. She had a complicated medical history having undergone spinal surgery, a tracheostomy and having experienced hypoxic brain injury. She was resuscitated and ventilated and a right subclavian central line was inserted as part of her management prior to transferring her to the intensive care unit (ITU). On chest x-ray the right central line catheter was noted to have taken a rather unusual route of traversing the midline (figure 1). As all ports were aspirating blood, the central venous pressure trace was of normal pattern and, as there were no issues using the line, it remained in situ and an anomalous brachiocephalic vein anatomy was considered to be the cause of the unusual $\mathrm{x}$-ray finding.
Various patterns of unusual brachiocephalic anatomy have been identified in the past particularly due to problems during embryogenesis. ${ }^{1}$ The pattern shown in our x-ray is due to the anomalous left brachiocephalic vein terminating in line with the right subclavian vein rather than in its usual lower position. The anomalous left brachicephalic veins usually runs behind the aortic arch and above the pulmonary artery. These anomalies may coexist with other great vessel and cardiac anomalies, including tetrology of Fallot and ventricular septal defects. ${ }^{2}$

Anatomical variations may occur, and they have implications for placement of central lines in the ED. Abnormally placed lines may be retained if they meet the characteristics and clinical need, as in our case. However, some of them may have to be removed if there is a clinical suspicion that they may cause additional harm or not be clinically useful.

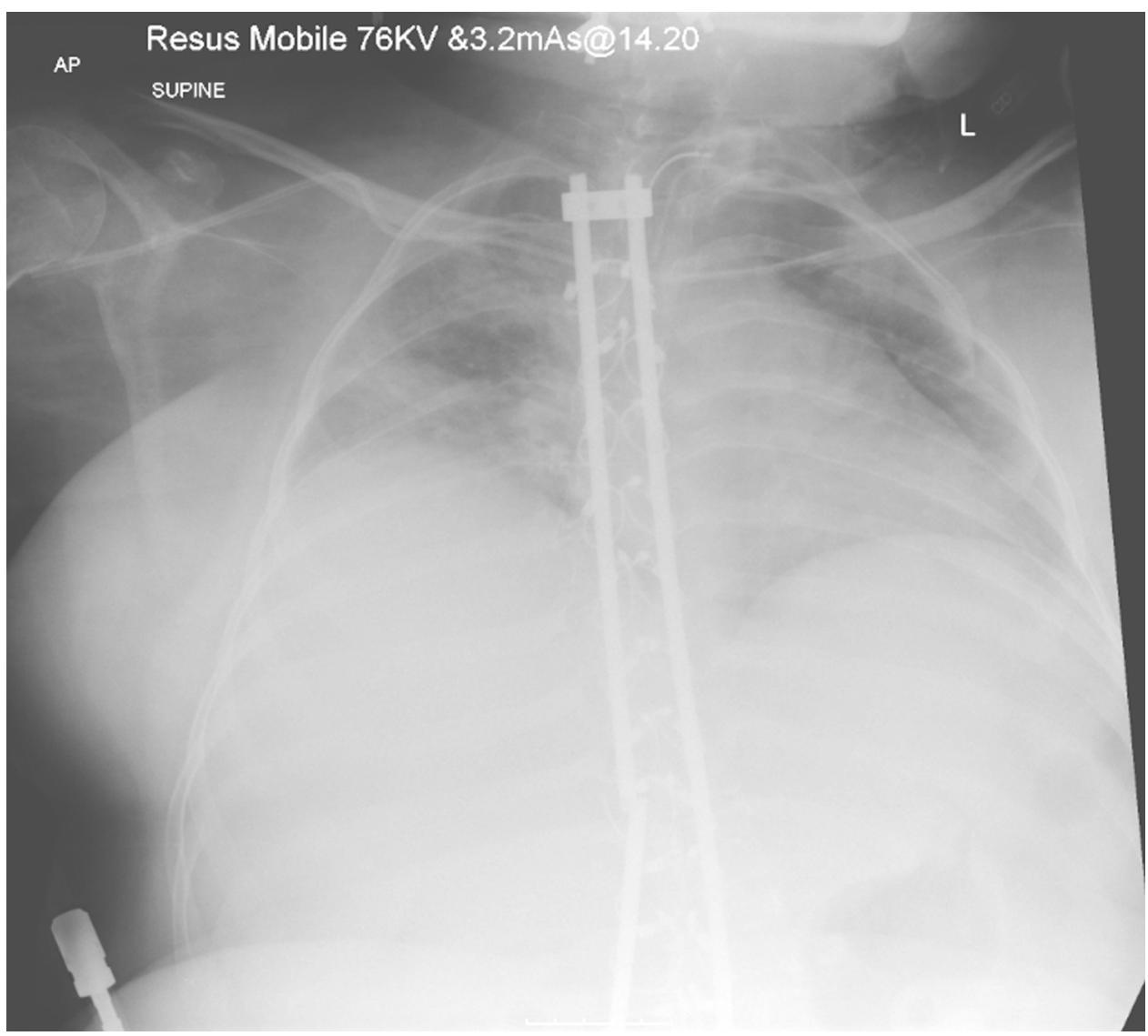

Figure 1 Chest x-ray: right subclavian catheter traversing the midline. 


\section{BMJ Case Reports}

Competing interests None.

Patient consent Obtained.
2. Choi JY, Jung MJ, Kim YH, et al. Anomalous subaortic position of the brachiocephalic vein (innominate vein): an echocardiographic study. Br Heart J 1990;64:385-7.

\section{REFERENCES}

1. Chen SJ, Liu KL, Chen HY, et al. Anomalous brachiocephalic vein: CT, embryology, and clinical implications. AJR 2005;184:1235-40.

This pdf has been created automatically from the final edited text and images.

Copyright 2010 BMJ Publishing Group. All rights reserved. For permission to reuse any of this content visit http://group.bmj.com/group/rights-licensing/permissions.

BMJ Case Report Fellows may re-use this article for personal use and teaching without any further permission.

Please cite this article as follows (you will need to access the article online to obtain the date of publication).

Hempling M, Koletzko A, Jaiganesh T. Misplaced central venous catheter?. BMJ Case Reports 2010;10.1136/bcr.04.2010.2902, date of publication

Become a Fellow of BMJ Case Reports today and you can:

Submit as many cases as you like

Enjoy fast sympathetic peer review and rapid publication of accepted articles

Access all the published articles

Re-use any of the published material for personal use and teaching without further permission

For information on Institutional Fellowships contact consortiasales@bmjgroup.com

Visit casereports.bmj.com for more articles like this and to become a Fellow 